\title{
The Influence of Performance Feedback Practices on Implementation of Teachers' Performance Appraisal in Public Secondary Schools in Makueni Sub- County, Kenya
}

\author{
Caren Mwikali Makumi, Janet Kavula Mulwa \& Jonathan Muema Mwania \\ School of Education, Humanities and Social Sciences, South Eastern Kenya University, Kenya
}

\begin{abstract}
The current study purposed to establish the influence of performance feedback practices on implementation of teachers' performance appraisal in Public secondary schools in Makueni Sub-County, Kenya. The study objectives sought to investigate the influence of timely and regular feedback, involving teachers and clear guidelines on implementing of performance appraisal of teachers in public Secondary Schools in Makueni SubCounty. This study was underpinned on Goal setting theory. Descriptive survey research design was adopted targeting 44 head teachers of public secondary schools, 563 secondary school teachers and 1 Teachers' Service Commission Human Resource Officer. Stratified Proportionate Sampling and simple random sampling methods got employed to select 22 principals and 56 teachers from the secondary schools. Census and purposive sampling techniques were applied to select 1 Teachers Service Commission Human Resource Officer. Questionnaires and interview schedule were adopted as tools for data collection. Validity and reliability of instruments was established by way of a pilot study and Split-half technique respectively. Data was analyzed qualitatively and quantitatively with the help of descriptive as well as inferential statistics with the aid of SPSS computer software. Quantitative data was presented by way of cross tabulation tables and frequency distribution tables. Qualitative data was organized into themes based on study objectives and presented in a narrative form. Correlation analysis was done using Pearson's Product moment Correlation (r). Analysis on Principals and teachers' responses indicated a positive interrelationship $(\mathrm{r}(20)=0.704, \mathrm{r}(20) 0.712, \mathrm{r}(20) 0.632$ and $\mathrm{r}(56)=0.783, \mathrm{r}(56)=$ $0.744, \mathrm{r}(56)=0.665$ all at $\mathrm{p}<0.05$ ) existing between timely and regular feedback, involving teachers as well as clear guidelines and implementing of teachers' performance appraisal respectively. The study concluded that regular and timely feedback, involving teachers and clear guidelines have positive influence on implementation of performance appraisal for teachers and need to be practiced in schools.
\end{abstract}

Keywords:Performance Feedback, Implementation, Performance Appraisal, Regular Feedback, Timely Feedback, Involving Teachers, Clear Guidelines

DOI: $10.7176 / \mathrm{JEP} / 12-33-06$

Publication date: November $30^{\text {th }} 2021$

\section{Introduction}

Performance appraisal is a systematic assessment of the performance of staff to understand their capabilities for advanced growth and development (Juneja, 2020). Bucklingham and Goodall (2019), indicated that feedback is about telling people what we think of their performance. Significant teacher evaluation involves an accurate examination of teaching effectiveness followed by feedback (Berbano, 2009). However Kluger and DeNisi (1996), argued that feedback could instead of improving performance lead to crippling of employees performance. This is consistent with Bucklingham and Goodall (2019), who established that telling people how we think of their performance does not help them succeed and telling them how they should improve inhibits learning.

Miki and colleagues (2015) indicated that about $75 \%$ of Japanese teachers reported receiving feedback from their school leader. This is consistent with National Center on Education and the Economy NCEE (2021), which indicated that teachers in Japan set their annual goals and at the end of the year assess their progress in consultation with head teachers. This conformed to Katsuno (2016), who observed that teachers in Japan have to account for their performance and competence.

Although Figazzolo (2013), stated that the essence of evaluation is to offer feedback so that teachers may improve their professional capability, Australian Institute for Teaching and School Leadership Limited (2012), indicates that teachers in Australia do not get the feedback they need to improve but that appraisal is done for administrative requirements. This is consistent with Elliot (2015), who stated that feedback and valid performance appraisal is not provided consistently in schools in Australia. Jensen and Reichl (2011), stated that a system of appraising teachers and feedback would enhance the effectiveness of teachers.

Tuma, Hamilton and Berglund (2018), observed that in USA majority of teachers reported receiving regular feedback which improved their instructional practice. This is consistent with Garet et al (2017) who indicated that feedback had some positive influence on teachers' classroom practice. Hammond (2013) established that at the final performance evaluation meeting, the teacher and principal reflect and discuss growth and attainment of 
goals.

Mpungose and Ngwenya (2014), observed that in South Africa the challenges that the head teachers faced, originated from lack of clarity of roles amongst others and recommended regular feedback from the education officials and workshops. This conforms to Olatunji (2017), who indicated that a fair assessment process involves open communication, constructive and honest feedback as well as employing agreed procedures consistently. Francine (2008), established that departments of education in South Africa ought to fund and execute a professional growth plan, which includes educators.

Danku, Dordor, and Bokor (2015), indicated that at the basic schools in Ghana Education Service (GES) performance criteria do not consider staff opinions. Agyei (2019), recommended communication effectiveness and dissemination of information to appraisees immediately after conducting evaluation of performance. Kwao (2019), concluded that the Performance Appraisal System (PAS) is not entirely regarded and affirmed by all staffs which has led to inadequate feedback, unknown performance standards and apathy of appraisal processes by teachers in Ghana Education Service. Adofo (2011), suggested a clear cut policy on performance appraisals in the GES in order to enhance on its conduct.

Abraham (2010), established poor feedback management in Kabale Municipality, Uganda. Charles (2018), suggested that management ought to ensure communication effectiveness and information dispersal to teachers immediately after the performance evaluation is done, and that the appraiser need to get full involvement of teachers and employ a more collaborative method during evaluations. Malunda and others (2016) observed that teaching is partly determined by how well and frequently teachers are appraised and recommended that the Ministry Of Education Science and Technology (MOESTs) need to develop standard formative evaluation tools for continuous teacher evaluation.

Kangema and Irungu (2018), concluded that when an evaluation system is complex employees may fail to understand it in full and that appraisals ought to be reviewed with the appraised. This was consistent with Werunga (2010), who suggested that the Teachers' Service Commission (TSC) in Kenya ought to cooperate with the teachers in determination of their own targets and that the head teacher need to develop performance assessment policy for all teaching staff jointly with them. Owino (2019), observed that TSC came up with the Teacher Performance Appraisal and Development (TSC TPAD) tool which is in accordance to TSC Code of regulations for teachers in Kenya, regulation 52(1) to enable teachers participate in the evaluation of their own performance and to strengthen supervision and monitoring. Owino (2019), states that the whole process of appraisal is currently being done online where head teachers oversee the process in their respective schools.

Previous studies did not pay much attention to factors influencing teachers' performance appraisal implementation in public high schools. To address a knowledge gap, this study examined the effect of performance feedback practices on teachers' performance appraisal implementation in secondary public institutions in Makueni Sub-county. Makueni sub-county was chosen for this study since implementation of performance appraisal was not being reflected in terms of improved public secondary school performance in other studies.

\section{Statement of the Problem}

Since the achievement of independence in 1963, the Kenyan government has devoted itself in enhancing education standards as a fundamental human right, to fight poverty and to achieve national development (Ministry of Education, 2008). Despite the commitment by TSC to enforce teachers' performance, factors affecting execution of teachers' performance evaluation remain largely unexplored. Iraki (2013), established that, Performance appraisal could positively impact learning and teaching within education centers if well implemented. Teachers' Service Commission Makueni Sub County office (2018), indicated that implementation of teachers' performance appraisal is not being reflected in terms of improved school performance in the Sub County since schools are still posting low grades in National examinations. Makueni Sub County Personnel office (2021), indicated that Makueni Sub County posted among other mean grades Es and D-(Minuses) from 2016 to 2019 in KCSE with a large number of students not qualifying for University entry. This was despite the use of performance assessment for public secondary school teachers within the sub- County.

Though in line with authorities there could be other factors derailing school performance, poor performance feedback practices could be affecting execution of performance appraisal for teachers thereby affecting teachers' productivity and students' performance in the Sub County. This may be affecting school performance and Makueni Sub County may lag behind in terms of social and economic development. To solve the problem, Teachers' Service Commission Makueni Sub County office (2018), states that TSC officials in the Sub County have been holding numerous meetings with principals, clinics and trainings for teachers on performance appraisal. This study was carried out to fill a knowledge gap on the impact of performance feedback practices on implementing of performance appraisal of teachers in public secondary institutions in Makueni sub-county, Makueni County. Gichuki (2015), established feedback communication problems in the performance appraisal system in Kenya. Werunga (2010), observed that teachers together with principals set targets for achievement 
and performance evaluation interview is carried out objectively. Gichuki (2015) and Werunga (2010), left a gap in that the studies were done in different settings hence this study topic is different from theirs.

\section{General Study Objective}

The current study aimed at investigating how performance feedback practices influenced implementation of performance appraisal of teachers in Public Secondary schools in Makueni sub-county, Makueni County, Kenya.

\subsection{Specific Study Objectives}

The following specific study objectives were adopted for this study:

i. To establish how timely and regular feedback affect teachers' performance appraisal implementation in public secondary schools in Makueni Sub- County.

ii. To determine how involving teachers in setting of targets influence implementing of teachers' performance appraisal in public secondary schools in Makueni sub- County.

iii. To investigate the effect that clear guidelines have on implementation of teachers' performance appraisal in public Secondary schools in Makueni Sub County.

\section{Literature Review}

Leonard, (2018), stated that feedback on performance is a communication process and there is need for regular follow up dialogue to determine its success. OECD (2009), states that evaluation and feedback indicated a strong positive impact on teachers as well as their work. This study sought to investigate the influence of timely and regular feedback, involving teachers and clear guidelines on implementing of teachers performance appraisal.

\subsection{Timely and Regular Feedback and Implementation of Teachers' Performance Appraisal}

Alubbe (2015) recommended that continuous feedback within the year need to be considered in depth. This conformed to Karugaba (2015), who indicated that, teachers' performance evaluation feedback lacked effectiveness as teachers did not receive timely as well as regular feedback on performance to enhance secondary school education performance. Gichuki (2015), recommended enhancement in communication of feedback amongst TSC, schools as well as teachers. However, Maurer (2011), indicated that feedback is good but consumes time and not necessary.

\subsection{Involving Teachers in Setting of Targets and Implementation of Teachers' Performance Appraisal} Stewart (2013), states that for evaluations to be consequential measures of feedback needs to be devised in cooperation with the profession of teaching. This conforms to Figazollo(2013), who stated that where teacher assessment plans and policies are envisioned with the involvement of teachers and their unions, far reaching methods earn teachers' trust and provide helpful information. Owuonda, Odera and Odhiambo (2020), observed that teachers should be included in designing of the performance assessment tool for teachers to build their positive attitude towards teacher performance evaluation. This is consistent with Kareithi(2018), who suggested that to have effective goal setting practices, teachers ought to be involved in coming up with goals to determine a transparent and objective criteria for appraisal which will inform them the basis of their evaluation. This conformed to Okemwa (2019), who proposed the need to actively involve teachers in discussing of performance appraisal feedback. However, Gibson (2020), established that teachers were less positive on the value of targets and felt that an adequate amount of their time was spent on target setting.

\subsection{Clear Guidelines and Implementation of Teachers' Performance Appraisal}

Kyakulumbye (2013), recommended clear observation of guidelines for coming up with performance goals that lead to favorable outcomes. This was in conformity to Ngeno, Bett and Kimutai (2013), who recommended that TSC ought to develop clearer policies to govern performance appraisal. Kangema and Irungu (2018), concluded that if appraisal is complex teachers may not understand it in full. The researchers further established that government policies were unfavorable in terms of career advancement and introduction of the policies in use. This was consistent with Hammond (1994), who cautioned on policy that had focus on introducing standards and claimed that it is not the standards that would enhance the education system, but how the standards were used.

\section{Research Methodology}

The adopted research design for this study was descriptive research where the target population comprised 44 principals and 563 teachers of public secondary learning institutions and 1 Teachers' Service Commission Human Resource Officer. Stratified Proportionate Sampling procedure was applied to stratify public secondary schools, after which simple random method of sampling was employed to select 22 principals of secondary schools and 56 secondary school teachers. Census and purposive sampling techniques were applied to select 1 Teachers Service Commission Human Resource Officer because of the number and because of possessing 
information that was useful for the study. This made a sample size of 79 subjects which is $12.9 \%$ of the target population of 608 subjects, which was considered as good enough for collection and analysis of data._Mugenda and Mugenda (2003), stated that a 10\% to 30\% sample size is good enough if well chosen.

The study was based on the goal setting theory of motivation by Dr. Locke Edwin in the 1960s. The theory indicates that goal setting is connected to performance of tasks (Juneja, 2011). Features of goal setting theory are: the will to work towards the achievement of goals, specific and clear goals, challenging and realistic goals, better and proper feedback of results as well as staff participation in goals (Juneja, 2011). Questionnaires and interview schedule were adopted as tools for data collection. Validity of the instruments for the research was established by way of a pilot study in 4 Public secondary schools which did not participate during the main study. Split-half technique was applied to determine reliability of research instruments. The results indicated a reliability of 0.78 and 0.75 for both principals and teachers respectively. Mugenda and Mugenda (2003), states that a coefficient of reliability at 0.7 or over is satisfactory. This was an indicator that the instruments were reliable.

Data was analyzed qualitatively and quantitatively using descriptive as well as inferential statistics with the aid of SPSS software. Quantitative data was presented by use of cross tabulation tables and frequency distribution tables. Qualitative data was organized into themes based on study objectives and presented in a narrative form. Correlation analysis was carried out using Pearson's Correlation (r) to determine the relationship between the dependent and independent variable. Significance level was determined at 0.01 in a two tailed test. The respondents were assured of confidentiality by requesting them not to write their names on questionnaires.

\section{Research Findings}

This study sought to investigate how performance feedback practices influence enforcement of performance assessment for teachers in public secondary institutions in Makueni sub-county. The first objective sought to investigate the impact of timely and regular feedback on implementing of teachers' performance evaluation in public secondary institutions within Makueni Sub County. In order to achieve this objective, principals were requested to indicate to what level they agreed with the Likert scale statements using 1-Strongly Disagree, 2Disagree, 3 - Undecided, 4- Agree and 5- Strongly Agree. The results were indicated in table1.

Table 1: Principals' responses on performance feedback practices

\begin{tabular}{|c|c|c|c|c|c|c|c|c|c|c|}
\hline \multirow[t]{2}{*}{ STATEMENTS } & \multicolumn{2}{|l|}{1} & \multicolumn{2}{|l|}{2} & \multicolumn{2}{|l|}{3} & \multicolumn{2}{|l|}{4} & 5 & \multirow[t]{2}{*}{ Total $\%$} \\
\hline & $\mathrm{F}$ & $\%$ & $\mathrm{~F}$ & $\%$ & $\mathrm{~F}$ & $\%$ & $\mathrm{~F}$ & $\%$ & $\%$ & \\
\hline $\begin{array}{l}\text { Timely and regular feedback has influenced } \\
\text { execution of teachers' performance evaluation } \\
\text { in the school. }\end{array}$ & 2 & $(10 \%)$ & & $3 \%)$ & $2(1$ & & & $\%)$ & $5(25)$ & $20(100 \%)$ \\
\hline
\end{tabular}

From the findings of the study in table 1 majority $(40 \%)$ of the principals agreed that timely and regular feedback influenced how teachers implemented their performance appraisals in the schools, $5(25 \%)$ principals strongly agreed that timely and regular feedback has an impact on enforcement of teachers' performance appraisal implementation. $2(10 \%)$ principals strongly disagreed with the statement that timely and regular feedback has an effect on administration of teachers' performance appraisal while $13 \%$ of the principals disagreed with the statement. 2(10) principals were undecided that timely and regular feedback has influenced execution of teachers' performance evaluation in the school. Teachers were requested to indicate their level of agreement with the statement in the Likert scale and the results of their responses are indicated in table 2.

Table 2: Teacher's responses on timely and regular feedback and implementation of teachers' performance appraisal

\begin{tabular}{lccccccc} 
Statement & $\mathbf{1}$ & $\mathbf{2}$ & $\mathbf{3}$ & $\mathbf{4}$ & $\mathbf{5}$ & Total \\
\hline $\begin{array}{l}\text { Timely and regular feedback } \\
\text { has influenced how teachers } \\
\text { implement performance }\end{array}$ & $2(3.6 \%)$ & $5(8.9 \%)$ & $5(8.9 \%)$ & $29(51.8 \%)$ & $15(26.8 \%)$ & $\mathbf{5 6}(\mathbf{1 0 0 \%})$ \\
assessment in the school. & & & & & &
\end{tabular}

From the findings of this study in table 2 , it was observed that $51.8 \%$ of the teachers agreed with the statement that timely and regular feedback influenced implementation of teachers' performance appraisal in the school. 15(26.8\%) teachers strongly agreed that timely and regular feedback had an effect on the way teachers' performance appraisal was being implemented while $8.9 \%$ of them disagreed with the statement that timely and regular feedback had any influence on implementing of teachers performance appraisal. 2 (3.6\%) teachers strongly disagreed with the statement that timely and regular feedback had an impact on enforcement of teachers performance assessment while $5 \%$ of them were undecided. Principals responded on teacher involvement in setting of appraisal targets. The results of their responses are indicated in table 3. 
Table 3: Principals responses on teacher involvement in setting of targets and implementation of teachers' performance appraisal

\begin{tabular}{|c|c|c|c|c|c|c|}
\hline \multirow{2}{*}{ STATEMENTS } & 1 & 2 & 3 & 4 & 5 & Total \\
\hline & f $\%$ & $\%$ & $\%$ & $\%$ & $\%$ & \\
\hline
\end{tabular}

influenced administration

of teachers' performance

assessment in the school.

The results of the findings in table 3 established that $45 \%$ of the principals agreed with the statement that involving teachers in setting of targets has influenced implementation of teachers' performance appraisal. 5(25\%) principals strongly agreed that involving teachers influenced administration of teachers' performance evaluation while $10 \%$ of them disagreed with the statement. 3(15\%) principals strongly disagreed with the statement that involving teachers had an impact on enforcement of teachers' performance appraisal. $5 \%$ of the principals were undecided whether involving teachers impacts administration of teachers' performance review. Table 4 indicates the results of responses from teachers on teacher involvement in setting of appraisal targets.

Table 4: Teacher's responses on teacher involvement in setting of targets and implementation of teachers' performance appraisal

\begin{tabular}{|c|c|c|c|c|c|c|}
\hline \multirow[t]{2}{*}{ Statement } & 1 & 2 & 3 & 4 & 5 & \multirow{2}{*}{$\begin{array}{c}\text { Total } \\
\%\end{array}$} \\
\hline & F \% & F \% & F \% & $\%$ & F \% & \\
\hline $\begin{array}{l}\text { Involving teachers in setting } \\
\text { of appraisal targets has } \\
\text { influenced the way in which } \\
\text { teachers' performance } \\
\text { evaluation is implemented in } \\
\text { the school. }\end{array}$ & $5(5.8 \%)$ & $6(10.7 \%)$ & $8(14.3 \%)$ & $25(44.6 \%)$ & $12(21.4 \%)$ & $56(100 \%)$ \\
\hline
\end{tabular}

From the findings of the study in table 4 it was noted that $44.6 \%$ of the teachers were in agreement that being involved in setting of appraisal targets had influenced administration of teachers' performance review .12(21.4\%) teachers strongly agreed that involving teachers had an impact on enforcement of teachers' performance evaluation while $10.7 \%$ of them disagreed with the statement $.5(5.8 \%)$ teachers strongly disagreed that involving teachers had an effect on enforcement of teachers' performance review while $8(14.3)$ were undecided. Principals indicated their responses on clear guidelines and the results of their responses are as indicated in table 5.

Table 5: Principals' responses on clear guidelines in performance appraisal and implementation of teachers' performance appraisal

\begin{tabular}{|c|c|c|c|c|c|c|}
\hline STATEMENTS & 1 & 2 & 3 & 4 & 5 & Total \% \\
\hline & f $\%$ & $\%$ & f $\%$ & $\%$ & $\%$ & \\
\hline $\begin{array}{l}\text { Clear guidelines } \\
\text { influence enforcement of } \\
\text { teachers performance } \\
\text { review in the school. }\end{array}$ & $4(20 \%)$ & $1(5 \%)$ & $1(5 \%)$ & $11(55 \%)$ & $3(15 \%)$ & $20(100 \%)$ \\
\hline
\end{tabular}

The results of the study in table 5 established that $55 \%$ of the principals agreed that clear guidelines in performance appraisal had an influence on implementing of teachers' evaluation of their performance in schools. $3(15 \%)$ principals strongly agreed that clear guidelines had an impact on implementation of teachers' performance assessment while 1(5\%) disagreed with the statement. 1(5\%) principal was undecided whether clear guidelines had an effect on administration of teachers' performance review while $4(20 \%)$ of them strongly disagreed with the statement. Teachers were requested to respond on clear guidelines and the results of their responses are presented in table 6.

Table 6: Teacher's responses on clear guidelines in performance appraisal and implementation of teachers' performance appraisal

\begin{tabular}{|c|c|c|c|c|c|c|}
\hline \multirow[t]{2}{*}{ STATEMENT } & 1 & 2 & 3 & 4 & 5 & Total \\
\hline & $\mathrm{F} \quad \%$ & F $\%$ & F $\%$ & $\mathrm{~F} \quad \%$ & $\mathrm{~F} \quad \%$ & $\%$ \\
\hline $\begin{array}{l}\text { Clear guidelines in } \\
\text { performance appraisal } \\
\text { influence administration of } \\
\text { teachers performance review } \\
\text { in the school. }\end{array}$ & $3(5.4 \%)$ & $5(8.9 \%)$ & $7(12.5 \%)$ & $24(42.9 \%)$ & $17(30.4)$ & $56(100)$ \\
\hline
\end{tabular}

The findings of the study in table 6 revealed that $42.9 \%$ of the teachers agreed that, clear guidelines in 
performance appraisal influenced administration of teachers' performance evaluation in the school. $17(30.4 \%)$ teachers strongly agreed that clear guidelines had an impact on enforcement of teachers' performance assessment while $8.9 \%$ of them disagreed with the statement. $3(5.4 \%)$ teachers strongly disagreed with the statement that clear guidelines influenced implementation of teachers performance review while $7(12.5 \%)$ teachers were undecided. The study sought to establish the relationship existing between the independent and dependent variables. Pearson's Correlation analysis was done for principals and teachers responses and the results are as indicated in table 7 and 8 respectively.

Table 7: Pearson's Correlation for Principals' Responses on Performance Feedback and Implementation of Teachers' Performance Appraisal

\begin{tabular}{|c|c|c|c|c|c|}
\hline & & $\begin{array}{l}\text { Timely and } \\
\text { regular } \\
\text { feedback }\end{array}$ & $\begin{array}{l}\text { Involving } \\
\text { teachers }\end{array}$ & $\begin{array}{l}\text { Clear } \\
\text { guidelin } \\
\text { es }\end{array}$ & $\begin{array}{l}\text { Implemen } \\
\text { tation of } \\
\text { Teachers' } \\
\text { performan } \\
\text { ce } \\
\text { appraisal }\end{array}$ \\
\hline \multirow[t]{2}{*}{ Timely and regular feedback } & Pearson Correlation & 1 & & & \\
\hline & $\mathrm{N}$ & 20 & & & \\
\hline \multirow[t]{3}{*}{ Involving teachers } & Pearson Correlation & $.622(* *)$ & 1 & & \\
\hline & Sig. (2-tailed) & .000 & & & \\
\hline & $\mathrm{N}$ & 20 & 20 & & \\
\hline \multirow[t]{3}{*}{ Clear guidelines } & Pearson Correlation & $.521(* *)$ & $.766(* *)$ & 1 & \\
\hline & Sig. (2-tailed) & .003 & .000 & & \\
\hline & $\mathrm{N}$ & 20 & 20 & 20 & \\
\hline \multirow[t]{3}{*}{$\begin{array}{l}\text { Implementation of } \\
\text { performance appraisal }\end{array}$} & Pearson Correlation & $.704(* *)$ & $.712(* *)$ & $.632(* *)$ & 1 \\
\hline & Sig. (2-tailed) & .000 & .000 & .000 & \\
\hline & $\mathrm{N}$ & 20 & 20 & 20 & 20 \\
\hline
\end{tabular}

** Correlation is significant at the 0.01 level (2-tailed).

8: Correlation for Teachers' responses on Performance Feedback and Implementation of Teachers' Performance Appraisal

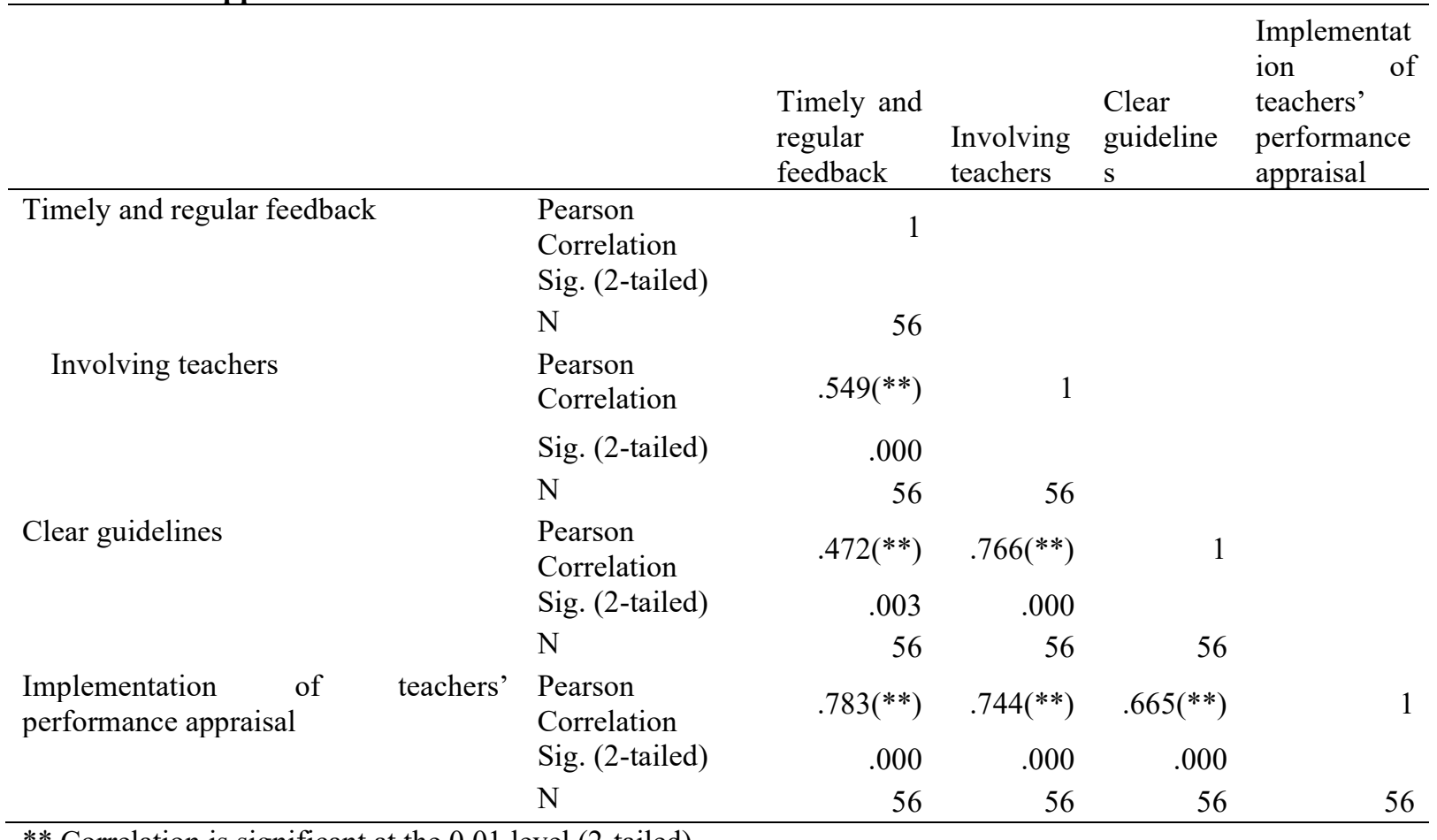

** Correlation is significant at the 0.01 level (2-tailed).

According to Jaadi (2019), a correlation of between 0.90 up to 1.00 or- 0.90 to -1.00 is an indicator to a very 
high positive or negative interrelationship, 0.7 to 0.90 or -0.7 up to -0.90 suggests a high positive or negative association, between 0.50 to 0.70 and -0.50 to -0.70 is suggestive of a moderate positive and negative correlation respectively, 0.30 to 0.50 as well as -0.30 to -0.50 denotes a low positive as well as negative interdependence, 0.00 up to 0.3 or 0.00 up to -0.30 shows insignificant interdependence. Pearson's correlation analysis indicated a high positive correlation of +0.704 at $p<0.5$ and +0.783 for head teachers and teachers responses on timely and regular performance feedback and execution of teachers' performance review respectively. The findings of this study concurred with Karugaba (2015), Allube (2015) and Gichuki (2015), who supported timely and regular feedback in schools. However, the study was inconsistent with Maurer (2011), who established that feedback is good but consumes time and not necessary.

In relation to clear guidelines in performance appraisal and implementing of teachers performance evaluation, Pearson's correlation analysis indicated a high positive correlation of +0.712 at $p<0.5$ and +0.744 at $\mathrm{p}<0.5$ for principals and teachers responses respectively. The findings of this study are consistent with Owuonda, Odera and Odhiambo (2020), Kareithi (2018), Okemwa (2019), and Karugaba (2015), who observed that it was necessary to involve teachers in setting their goals. The findings of this study contradicted Gibson (2020), who observed that teachers were less positive on the value of targets and felt that their time was spent on target setting.

Pearson's correlation analysis indicated a moderate positive relationship of +0.632 at $\mathrm{p}<0.5$ and 0.665 at $\mathrm{p}<0.5$ for both principals and teachers responses on involving of teachers in setting of appraisal targets and enforcement of teachers' performance assessment respectively. The findings of this study concur with Kyakulumbye (2013), Ngeno, Bett, Kimutai (2013) and Kangema and Irungu (2018) who established the need for clear policies for teachers. The findings of this study contradicted Hammond (1994), who cautioned on policy that had focus on introduction of standards and claimed that it is not the standards that would enhance the education system, but how the standards were used.

\section{Conclusions}

This study, made the following conclusions as per the research objectives and study findings: Performance feedback had an influence on the way in which performance review for teachers was being executed in public secondary institutions in Makueni Sub-County. This can be achieved through timely and regular feedback, involving teachers and having clear guidelines. There was a positive association $(\mathrm{r}(20)=0.704, \mathrm{r}(20) 0.712, \mathrm{r}$ (20) 0.632 and $\mathrm{r}(56)=0.783, \mathrm{r}(56)=0.744, \mathrm{r}(56)=0.665$ all at $\mathrm{p}<0.05)$ existing between timely and regular feedback, involving teachers and clear guidelines and teachers' performance appraisal implementation respectively. The study also concluded that parameters with the highest influence on enforcement of teachers' performance assessment were timely and regular feedback as well as involving teachers for both principals and teachers. Clear guide lines had the least influence on implementation of teachers' performance evaluation.

\section{Recommendations}

The study recommended that the Teachers' Service Commission should offer regular and timely performance feedback to teachers. This ought to include sensitizing school heads on the importance of regular and timely performance feedback. The study also recommends school heads to involve teachers in setting of appraisal targets and having clear guidelines on performance appraisal in the school.

\section{REFERENCES}

Abraham, A. ( 2010) The Effectiveness of Teachers' Performance Appraisal in Secondary Schools in Kabale Municipality, Munich, GRIN Verlag, https://www.grin.com/document/207381

Adofo,P.S. (2011). An Evaluation of the Performance Appraisal System and Its Effect on Employee Performance: A Case Study of Selected Senior High Schools In The Kwahu-South http://dspace.knust.edu.gh/bitstream/123456789/4441/1/PATRICK\%20SACKEY\%20ADOFO.pdf

Agyei, A. J. (2019). Performance Management and Appraisal as Tools for Improving Public Senior High School Teachers Quality In Wa Municipal Ghana. https://www.researchgate.net/publication/342165247

Alubbe,F. (2015). Factors Influencing the Implementation of the Teachers Performance Appraisal Systems; A Case of Public Secondary Schools in Westlands ConstituencyinKenya.http://erepository.uonbi.ac.ke/bitstream/handle/11295/90475/Alubbe\%20

Australian Institute for Teaching and school leadership limited (2012).Australian Teacher Performance and Development. Frame Work Consultation Proposal. https://docs.education.gov.au>other

Berbano,E. (2009). Teacher Evaluation a Conceptual Framework and Examples of Country Practices.www.academia.edu

Bucklingham, M. \& Goodall, A. (2019). The Feedback Fallacy. https://hbr.org >the-feedback-fallacy

Charles,M. (2018). On Epistemological Dynamics and Incorporation of Appraisal Practice in Kamplala Archdiocesan Secondary Schools https://doi.org/10.42236/oalib.1105052 
Danku,L.S., Soglo,N.Y., \& Dordor,F.(2015). Performance Appraisal in the Ghana Education Service, the Case of Basic School Teachers in Ho Municipality International Journal of Managerial Studies and Research (IJMSR) Volume 3, Issue 6, June 2015, PP 117-133 ISSN 2349-0330 (Print) \& ISSN 2349-0349 (Online) www.arcjournals.org https://www.arcjournals.org/pdfs/ijmsr/v3-i6/15.pdf

Elliot, K. (2015). Teacher Performance Appraisal: More about performance or Development? Australian Journal of teacher education, 40(9). http://dx.doi.org/10.14221/ajte.2015v40n9.6

Figazzolo, L. (2013). The Use and Misuse of Teacher Appraisal: An Overview of Cases in the Developed World. https://teachertaskforce.org $>$ files

Francine, C. (2008).Teacher Quality, Appraisal and Development: The Flaws in the IQMS. Perspectives In Education.https://www.researchgate.net/publication/289284692_Teacher_quality_appraisal_and_developm ent_The_flaws_in_the_IQMS

Garet, M.S., Wayne,A.J., Brown,S., Rickles,J.,Song, M.,\& Manzeske,D.(2017).The Impact of Providing Performance Feedback to Teachers and Principals.(NCEE2018-4001). Washngton, DC: National Centre for Education Evaluation and Regional Assistance, Institute of Education Sciences, U.S Department of Education http://ies.ed.gov/ncee.

Gibson. C. (2020). Exploring the Relationship Between Teacher Workload and Target Setting.www.educationgov.Uk/contactus

Gichuki, M.G. (2015). Teachers Perception of The Performance Appraisal System Effectiveness in Public Secondary Schools in Naivasha Gilgil Districts,NakuruCounty.http://irlibrary.ku.ac.ke/bitstream/handle/123456789/10926/Teachers\%20percep ons $\% 20$ of $20 \%$ the $\%$

Hammond, L. D. (1994). Standards for Teachers. Washington, DC: American Association of Colleges For Teacher Education

Hammond, L. D. (2013). Albemarle County Public Schools Teacher Performance Appraisal:Anoverview.https://inside.k12albemarle.org/acps/staff/TPA/Documents/Overview\%20of\%20the \%20TPA.pdf

Iraki, M. (2013). Teachers Perception of The Role of Performance Appraisal in Enhancing Teaching and Learning: A Case of Public Secondary Schools in KiambuCounty,Kenya.http://irlibrary.ku.ac,ke/bitstream/handle/123456789/7239/Ira20Margar...

Jaad, Z. (2019). Every Thing You Need to Know About Interpreting Correlations. towardsdatascience.com \&gt; everything...

Jensen,B., \& Reichl, J. (2011). Better Teacher Appraisal and Feedback: Improving Performance. Grattan Institute, Melbourne, Australia

Juneja,P.(2011).Goal Setting Theory of Motivation. https://www.managementsstudyguide.com> ...

Juneja, P. (2020). Performance Appraisal. https://www.management study guide

Kangema ,J. \& Irungu,C. (2018). An Analysis of Teacher Performance Appraisal and Their Influence on Teacher Performance in Secondary Schools in Kenya. International Journal of Education Voll1 no. 1 august 2018 pp.93-98 doi:http://dx.doi.org/10.17509/ije.v11148

Kareithi, M.W. (2018). Effect of Performance Appraisal System on Performance of Secondary School Teachers in Kirinyaga West Sub County, Kenya. 41.89.49.13>bitstream>handle

Karugaba, A. (2015). Effectiveness of Teachers' Performance Appraisal Feedback in Secondary Education Performance: The Case of Selected Public Secondary Schools in Bukoba MunicipalCouncil.http://scholar.mzumbe.ac.tz/bitstream/handle/111921068/MBACM_Adelina\%Karugaba_ 2015.pdf?se...

Katsuno, M.(2016). Teacher Evaluation Policies and Practices in Japan: How Performativity

Kyakulumbye, S. (2013). Appraisal System and Staff Performance in Selected Secondary Schools in Uganda: A Comparative Case Against Public Service AppraisalSystem.https:/www.westeastiinstitute.com/wpcontent/uploads/2013/04/ORL13-206-stephenkyakulumbye.pdf.

Kluger ,N.A \& DeNisi,A.(1996).The Effects Of Feedback Intervention on Performance: A Historical Review, A Meta-Analysis, and A Preliminary Feedback Intervention Theory, Psychological Bulletin,Vol.119, No.2225238

Kwao, M.P.(2019)Performance Appraisal System in the Ghana Education Service and Its Effectiveness on Teachers' Performance in the Ada East District URI: http://ugspace.ug.edu.gh/handle/123456789/34839

Leonard, K.(2018). What Is Performance Feedback.smallbusiness.chron.com>performa

Makueni Sub County Personnel Office. (2021). KCSE 2016- 2019 Performance Makueni Sub County

Malunda,P., Onen,D., Musaazi,J.C.S. \& Oonyu,J.(2016). Teacher Evaluation and Quality of Pedagogical Practices. International Journal of Learning, Teaching and Educational Research vl.15,no.9,pp.118133www.researchgate,net>publication 
Maurer,R.(2011).Chapter 1 Feedback Toolkit:16 tools For Better Communication in the Work Place, Second Edition,Productivity Press.

Miki,T., Pont,B., Figueroa,D.T. Peterka,J., \& Fraccola.S.(2015).Education Policy Outlook Japan

Ministry of Education. (2008). Safety Standards Manual For Schools in Kenya .sglobal.org>uploads>2017/01

Mpungose,J.E.\&Ngwenya,T.H.(2014). Managing Teacher Performance and Its Appraisal: Dilemmas of School Principals. Problems of Education in the 21 St Century. 62:74-85.https://hdl.handle.net/10321/1240

Mugenda, M.O. \& Mugenda, G.A. (2003). Research Methods: Quantitative and Qualitative Approaches. Nairobi, Kenya-Acts press.

National Center on Education and the Economy NCEE(2021).Top Performing CountriesJapan.ncee.org $>$ country $>$ japan

Ngeno,W.C.(2013). The Performance Appraisal Policy and Tools Used by the Kenya Teachers Service Commission in Bomet Constituency Kenya International Journal of Humanities and Social Science Vol. 3 No. 16 [Special Issue - August 2013] 229

Okemwa,O.J.(2019) Influence of Teachers Performance Appraisal in Public Secondary Schools in Kenya: A Case of Selected Schools in Nakuru Town Sub County. International Journal of Economics Commerce and Management Vol vii issue 11

Olatunji,O. (2017). Educators' Perspectives of Fair Performance Appraisal Practices in Gauteng Independent schools https://repository.up.ac.za/bitstream/handle/2263/65460/Olatunji_Educators_2017.pdf?sequence=1\&isAllo wed $=\mathrm{y}$

Owino, A. (2019). TSC TPAD: Online Filing of Teachers Performance \&Appraisal Development (TPAD) Form. https:www.kenyans.co.ke>news $>358$..

Owuonda,O.O., Odera,F. and Odhiambo,R. (2020). Teachers Attitude towards Teacher Performance Appraisal policy to Public Secondary School s' Academic Achievement in Homa Bay County, Kenya International Journal of Education and Research Vol. 8 No. 8 August 2020 https://www.ijern.com/journal/2020/August2020/03.pdf

Stewart, V.(2013).Teacher Evaluation an International Perspective. www.edweek.org>2013/03

Tuma, A. P., Hamilton, L. S. \& Berglund, T. (2018). A Nationwide Look at Teacher Perceptions of Feedback and Evaluation Systems. Findings from American Teacher Panel. https://doi.org/10.7249/RR2558

Teachers' Service Commission Makueni Sub County office. (2018). Implementation of Performance Appraisal.

Werunga, K.S. (2010). Teachers' Perceptions on Performance Appraisal Feedback in Secondary Schools Within Bungoma East Sub County Kenya.ir-library.ku.ac.ke> handle

Wright, L. L. \& Lake, D.A. (2015). Basics of Research for the Health Profession. http://www.pt.armstrong.edu>3.1variables.htm 